\title{
The Czech Structuralist Tradition and a Model of Translation-RElated Semiotic ANALYSIS
}

\begin{abstract}
This paper is a follow-up study on the influence of Czech structuralism on Czech translation theory. The pilot research paper (Zehnalová 2015) aimed at introducing Czech structuralism as a tradition firmly rooted in functionalism and distinguished by the semiotic account of language as communication embedded within its social-cultural environment, by dynamic notions of function and meaning-making, by concepts of potentiality, intersubjectivity, open structure and style as a unifying principle that integrates all textual levels and is itself integrated into the semiotic perspective. The potential of Czech structuralism for Translation Studies was demonstrated by developing a model of semiotic text analysis. The present paper further explores these concepts theoretically, with a special focus on the semiotic perspective as an integrating principle and on its usefulness for translation-oriented text analysis. It seeks to substantiate the model by providing further illustrative examples and to draw translation-relevant conclusions.
\end{abstract}

\section{Keywords}

Czech structuralism; functionalism; Czech translation theories; style; semiotic text analysis

\section{Introduction}

The present paper is a follow-up study on the influence of Czech structuralism on Czech and Slovak translation theories. The pilot study (Zehnalová 2015) presented a model of semiotic analysis that was developed as a tool to be used for 
translation purposes, i.e. for source text (ST) and target text (TT) analyses and interpretations, predominantly literary STs and TTs, as a part of the translation process and possibly the process of translation quality assessment.

The aims of the study are: (1) to sum up the key theoretical notions and relate them to current research; (2) to briefly introduce the model and to further explore the semiotic perspective as an integrating principle of text interpretation; (3) to test the usefulness of the model as a tool for translation-oriented text analysis by presenting more illustrative examples (including a passing reference to the visual aspect of literary texts) and to draw translation-relevant conclusions.

\section{Theoretical background and key notions}

The pilot research paper argued that Czech structuralism, as represented by the Prague Linguistic Circle, is a functional approach to the study of language that was instrumental in establishing functional linguistics. In spite of the label structuralism, and in spite of the fact that it was influenced by Russian formalism and is actually referred to as formalism by some authors, it is a decidedly functionalist tradition informed by Bühler's conception of language functions. Czech structuralism/functionalism perceives language dynamically from the point of view of the goals that language serves in human activity, and elaborates the concept of language functions. It is thus not to be associated with atomistic, static and formalist accounts of language. The paper also argued that it is directly linked to Czech and Slovak thinking regarding translation, and that even nowadays it has a great potential for Translation Studies - a potential which has not yet been fully utilised.

The concepts that concurrently (a) go back to the Prague linguists, (b) are crucial for the Czech and Slovak translation theories and (c) are of interest to contemporary translation research include:

- the semiotic account of language and its use as communication embedded within its social-cultural environment;

- the study of language functions and the dynamic notion of text function;

- the concept of text as an open structure conceived of as a networked system of both textual and extra-textual elements;

- the concept of meaning as a unity that integrates form and content and includes the human factor of meaning-making related to the concepts of potentiality and intersubjectivity;

- the concepts of style as a unifying principle integrating all textual levels and integrated into the semiotic perspective.

The semiotic and social-cultural approach to the study of language is a trait common to British and Czech functionally oriented linguistics. This orientation towards the social and the semiotic is the reason why both traditions have provided 
support and inspiration for Translation Studies. The British tradition, specifically Hallidayan systemic functional linguistics, historically situated in more convenient conditions, has had a vast impact on a great number of discourse-analytically oriented translation scholars and approaches, and up to the present day it continues to inform research that investigates translation as social communication exploiting both verbal and nonverbal meaning resources. Czech functionalism, due to its different historical context, has not been so lucky; its influence on theorising translation has mostly been limited to the Czech and Slovak socio-cultural environments and it was supressed for ideological reasons for a long time. Still, its influence, specifically on Levý and on Popovič, has been considerable. Thanks to the fact that these scholars could draw on the functional basis set up by the Prague linguists, they developed accomplished and pioneering accounts of translation phenomena.

As already mentioned, the study of language functions forms the very foundation of Czech structuralism, and the notion of the aesthetic function, which is of special relevance for literary text interpretation, is one of its main tenets. It was elaborated by Mukařovský along with the concepts of aesthetic norm and aesthetic value; all three notions are conceived of as dynamic and procedural (Fořt 2006: 132-134). The notion of language functions and text functions has been vital for linguistically oriented approaches to translation from the beginnings of Translation Studies as an independent field of study in the 50s to the current approaches rooted in discourse analysis, genre analysis and pragmatics. Although definitions of function (possibly subsumed into the concepts of text type or genre purpose) differ, as do opinions on the importance of the ST function on the one hand and the TT function/purpose on the other, the notion of function is nevertheless one of the key notions in Translation Studies. And because function relates a given text to its socio-cultural environment, it is an inherently dynamic notion which is tied in with the others previously mentioned - the concept of text as an open structure and the concept of meaning as meaning-making that includes human agents.

The degree to which the dynamic character of meaning is acknowledged varies from scholar to scholar and from approach to approach, but historically speaking there has been a strong tendency to move away from static and essentialist to non-essentialist dynamic views. This tendency is of course a part of the overall development of humanities as influenced by various strands of post-structuralist and post-modernist thinking. Within the context of Translation Studies, this inclination can be traced to the functionalist approaches of the 1970s and 80s and to the subsequent cultural, ideological and sociological "turns" that highlight the dynamics of context, the potentiality of meaning and the role of translators and other human agents as mediators in intercultural communication. In the Czech translation tradition, this development was ushered in by Levý and by his focus on text interpretation and on the translator's decision-making process as far back as the beginning of the 1960s.

In the past, the concept of style as a matter of achieving textual effects and as a matter of the translator's interpretation and choice was quite readily 
acknowledged, e.g. by Catford (1965) and Nida and Taber (1969), but hardly ever systematically studied. "Style is nominally an important factor in translation, but there are few detailed or satisfactory discussions of its role within translation theory" (Snell-Hornby 1988: 119). Within the Czech and Slovak translation theories, the situation has been different, and it can be argued that it is the aspect of style and the area of stylistics where the influence of Czech functionalism on Czech and Slovak Translation Studies has been the strongest. Scholars of the Prague School considered style to be a unifying principle interrelating all levels of a text, and conceived of meaning as a fusion of form and content. They studied the style of both literary and non-literary texts; literary text style was the focus of Mukařovský's work on poetic function, foregrounding and semantic gesture, while Havránek developed the theory of functional languages/styles. In his literary translation theory, Levý declares that the preservation of style is important yet problematic in translation. For him, the unifying principle and the value to be preserved in translation is the hierarchically higher notion of the ideo-aesthetic value of the text. This holistic value can be preserved by applying functional and hierarchical principles, i.e. by considering the function of individual elements in higher order units (1998: 56,132). Popovič on the other hand argues that "translation is a matter of style" (1975: 27). A comparison of Levý and Popovič's statements about the role of style in translation might suggest that they were in disagreement, but as is often the case, we need to consider their use of this concept rather than the statements themselves. Actually, Popovič defines style similarly to Levý's ideo-aesthetic value as a high order notion of "a dynamic configuration of expressive features of a text" (1975: 287), as an integrating factor interweaving all linguistic levels with the thematic level and as an assurance of the TT's coherence. This line of thinking relates well to current research. After about 2000, style and its relevance to translation has become a rewarding research area on an international scale. In her Stylistic Approaches to Translation, Boase-Beier states: "Literary translation can be seen as the translation of style because it is the style of a text which allows the text to function as literature" (2006: 114).

The goal of the pilot and the present studies is to demonstrate the potential of Czech structuralism/functionalism for Translation Studies by developing a model of semiotic text analysis. The model is based on Miroslav Červenka's 1992 monograph Významová výstavba literárního díla (The Meaning Structure of Literary Works). Cervenka is one of the successors of the Prague Linguistic Circle and his ideas are thus in accord with the above-mentioned tenets. He focuses on investigating the semiotics of literary works of art and identifies the literary text as:

- a structure unifying lower order and higher order signs;

- an open structure, a work of an individual author interpreted by its recipients and interacting with its environment;

- a work of literature and as such characterized by high variety (each element is simultaneously incorporated into several systems). 


\section{The model of semiotic text analysis}

Before introducing the model, I should offer a word or two of warning. The first one concerns the static schemes that are used. These will have to suffice, even though a semiotic account of (literary) communication is supposed to heed what Torop (2000: 603) calls the dynamism of description and even though there is nothing static in a semiotic account of translation: "Nothing is fixed in sign translation: the translating text-sign, the translated text-sign, the (non)linguistic codes, the translator, the translational and general cultural norms, all are subject to continual interaction and change, even to a minute degree" (Gorlée 1993: 231). The second warning has to do with the fact that the model mostly utilizes Saussure's dyad and only partially Peirce's triad. This is due to the fact that Červenka chose to develop his account this way and the presented model follows his approach. I am aware of the fact that for translation purposes, most authors prefer to draw on Peirce rather than on Saussure. Nevertheless, Cosculluela, who presents a Peircean view on translation, claims that prominent translation scholars, BassnettMcGuire, Toury, Larose, Hatim and Mason "appear to be mixing Peirce's semiotics and Saussure's semiology" (2003: 113), so following suit will hopefully not reduce the model's efficacy.

The following symbols are used within the model:

\begin{tabular}{|l|c|c|c|}
\hline \multirow{2}{*}{ Complexes } & \multicolumn{3}{|c|}{ Hierarchical level } \\
\cline { 2 - 4 } & Elementary sign & Complex signs & Attached meaning \\
\hline signifier & $\mathrm{a}$ & $\mathrm{A}, \mathrm{A}^{\prime}, \mathrm{A}^{\prime \prime}$ & $\alpha$ \\
\hline signified & $\mathrm{e}$ & $\mathrm{E}, \mathrm{E}^{\prime}, \mathrm{E}^{\prime \prime}$ & $\varepsilon$ \\
\hline sign (as a whole) & $\mathrm{s}$ & $\mathrm{S}$ & - \\
\hline
\end{tabular}

Table 1. Symbols used for meaning complexes

\begin{tabular}{|c|c|}
\hline Symbol & Meaning \\
\hline$\rightarrow$ & incorporation into higher complex \\
\hline$\leftrightarrow$ & meaning-making relation \\
\hline
\end{tabular}

Table 2. Other symbols

Text examples are taken from the short story Snow by Ann Beattie available in the Appendix. Definitions of the signified discussed are taken from Macmillan Dictionary and Thesaurus: Free English Dictionary Online available at http:// www.macmillandictionary.com/.

The model is designed to serve as an analytical tool to help the translator first interpret the ST, i.e. uncover the way in which various meaning resources are used and combined to create a meaningful coherent whole, and then to look for solutions to problems brought about by the interlingual and intercultural transfer. Problem solving refers to the process of the translator's decision-making, which 
is based on his/her ST interpretation and whose aim is to create another meaningful coherent whole, the TT.

In what follows, the model is described in two steps. First, the process of semiosis is introduced. Second, different types of contexts are identified. The goal of these two steps is to trace the move from low order signs to higher and higher order signs and thus to illuminate the way in which meaning is being created in the ST in order for the move to be re-traced and for the meaning to be re-created by the translator in the TT. In Section 4, the usefulness of the model is tested.

\subsection{The process of semiosis}

For the process of semiosis analysed for the purposes of translation, the terms semiotranslation and translational semiosis as coined by C. S. Peirce (Torop 2000: 603) could be used. The basic element of the process of semiosis/translational semiosis is the individual sign. It is a unity of the signifier and the signified as represented by the following scheme:

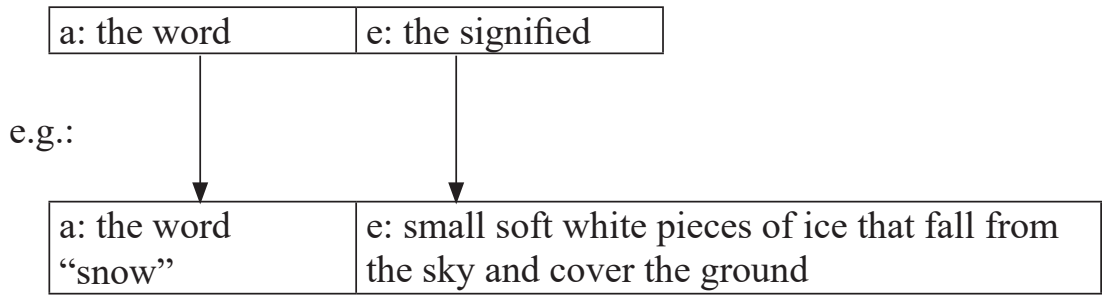

Figure 1. Individual sign

The process of semiosis begins - the individual sign is incorporated into other signs. It can be exemplified by the metaphorical sign "snow is love" and the way this sign is incorporated into the sign "meaningful values":

\begin{tabular}{|l|l|l|}
\hline $\begin{array}{l}\text { a: } \\
\text { the word "snow" }\end{array}$ & \multicolumn{2}{|l}{} \\
\cline { 1 - 2 } $\begin{array}{l}\text { e: } \\
\text { small soft white pieces of } \\
\text { ice that fall from the sky } \\
\text { and cover the ground }\end{array}$ & $\begin{array}{l}\text { A: } \\
\text { small soft white pieces of } \\
\text { ice that fall from the sky } \\
\text { and cover the ground }\end{array}$ & \\
\hline & $\begin{array}{l}\text { E: } \\
\text { love }\end{array}$ & $\begin{array}{l}\text { A': } \\
\text { love, friendship, home }\end{array}$ \\
\cline { 2 - 3 } & & $\begin{array}{l}\text { E': } \\
\text { meaningful values }\end{array}$ \\
& &
\end{tabular}

Figure 2. The metaphorical sign "snow is love" 
Then semiosis continues, signs form contexts and contexts form other contexts (other signs) as illustrated by Figure 3:

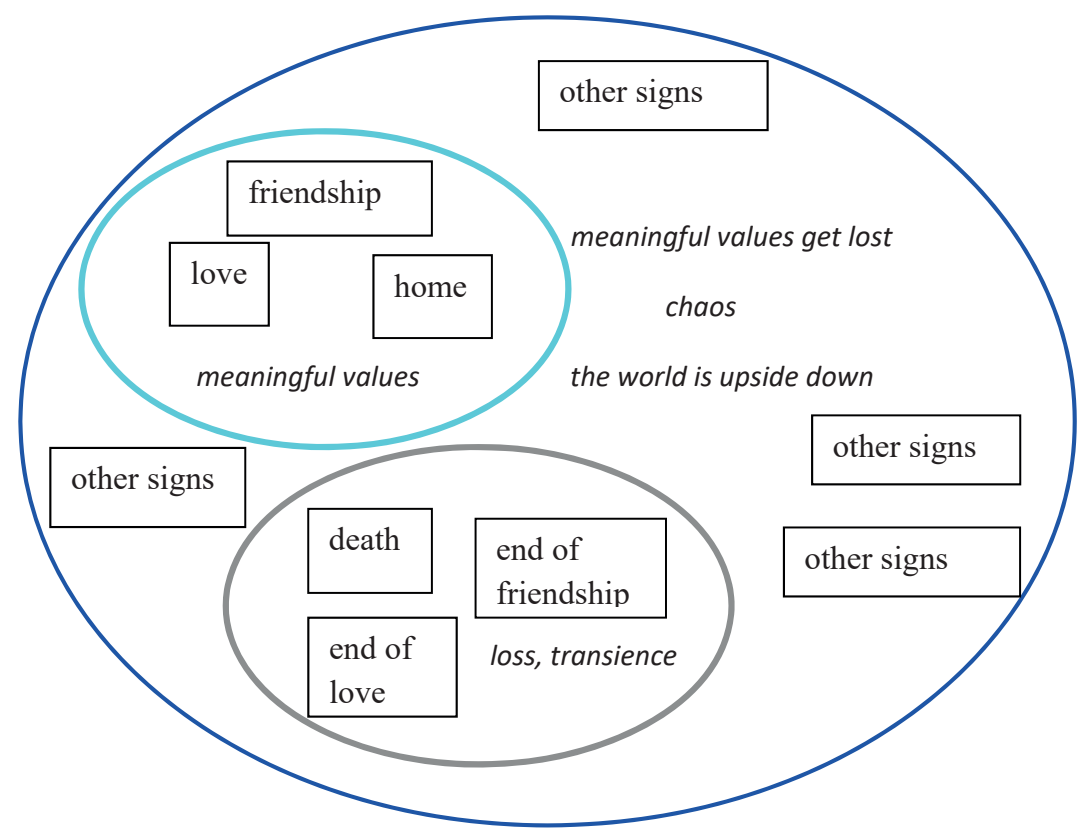

Figure 3. Context consisting of higher order complex signs

Semiosis continues and the text (consisting of contexts, i.e. higher order complex signs) becomes a sign. Then the process of semiosis continues and:

- the text as a sign (and along with other texts-signs) constitutes the author's work and style;

- the author's work becomes a sign (and along with other signs constitutes a literary movement, e.g. minimalism);

- minimalism becomes a sign (and along with other signs constitutes a literary/cultural context, e.g. the American literary/cultural context);

- the American literary/cultural context becomes a sign (and along with other signs constitutes a universal human context).

The textual and extra-textual process of semiosis is captured by Figure 4: 


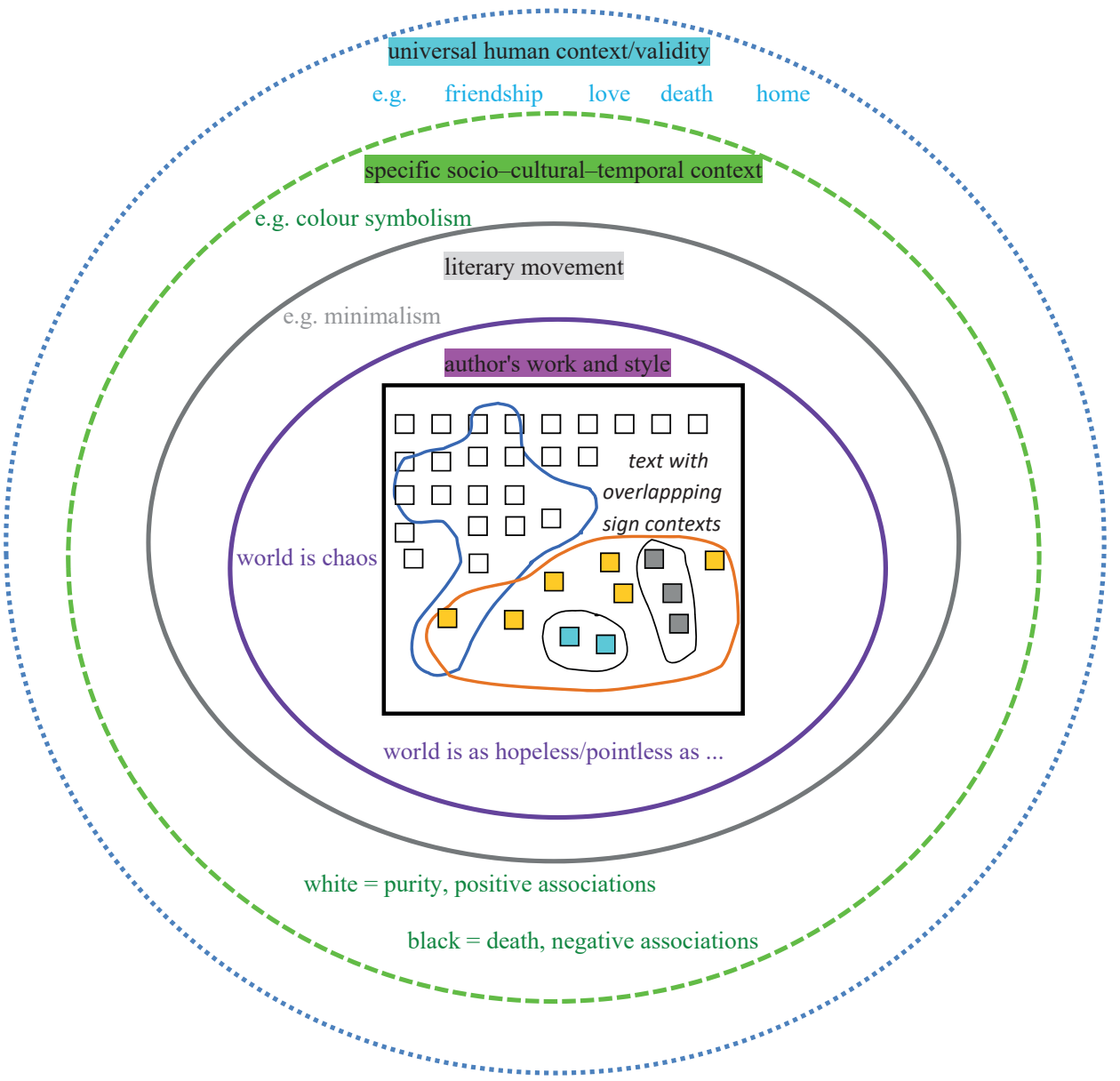

Figure 4. The textual and extra-textual process of semiosis

\subsection{Types of meaning contexts}

In the second, main part of the model, the aim is to identify different types of meaning contexts. As explained above, Červenka conceives of the literary work as a sign and a dynamic set of meanings, and highlights the principle of the hierarchical arrangement of literary works - the meaning elements are signs, and the lower order meaning elements constitute higher level systems (signs). The multiplicity of these complex signs arises from the fact that:

- the elementary sign can be incorporated either into the signifier or the signified of the complex sign or into the complex sign as a whole; 
- the higher level sign integrates either the signifier or the signified of the elementary sign or the elementary sign as a whole.

As a result, a wide theoretical range of possible relations between the elementary and the complex signs arises. Based on Roland Barthes' scheme (ERC)RC, Červenka first formulates preliminary and tentative combinations of elementary and complex sign levels, and subsequently identifies and describes these types of meaning contexts:

- metonymical context

- metaphorical context

- form activation context

- metalinguistic and intertextual context

- mythical context

- montage context

The contexts are not mutually exclusive; on the contrary, they presuppose each other and every element enters several contexts simultaneously, including contexts of different types.

Based on Červenka's analyses, the pilot study designed a translation-oriented semiotic model. It is meant as a tool intended to help translators with (a) ST text interpretation and (b) with their decision-making resulting in TT re-creation. The model might also be employed within the context of translation criticism as a tool to identify shifts in the TT and to describe their nature (e.g. whether a specific metaphorical context or a metaphorical meaning of the whole text was or was not re-created in the TT).

\section{Types of meaning contexts: Comments and examples}

Now I will seek to give a brief yet comprehensive description of the individual types of context and demonstrate the relevance/usefulness of the model by means of illustrative examples.

\subsection{The metonymical and metaphorical contexts}

Before discussing these contexts, I would like to at least hint at their broader background. For obvious reasons, I will do so by referring to Jakobson, who distinguished two poles of "human behaviour" - the metaphorical and the metonymic, associated them with all types of human behaviour, especially linguistic behaviour, and by doing so "sparked off a wave of post-structuralist research into metaphor and metonymy in French-speaking countries and the development of 'metaphorology' in Europe (Nuyts 2007: 601). 


\subsubsection{Metonymical context}

The basic scheme of the metonymical context is: $\mathrm{e} \rightarrow \mathrm{E}:$

The signified of elementary signs (lower order signs) create the signified of the meaning complex (higher order sign). Elementary signs are symbols (i.e. the relation a $\leftrightarrow$ e is unmotivated), and they form the complex sign E. As with other contexts, there is an attached meaning context $\alpha \leftrightarrow \varepsilon$ : the arrangement of elementary signs (i.e. chronological and semantic relations) becomes the signifier $\alpha$ and its meaning is $\varepsilon$. The attached meaning context merges with the signified $\mathrm{E}$ into the complex signified $E^{\prime}$ :

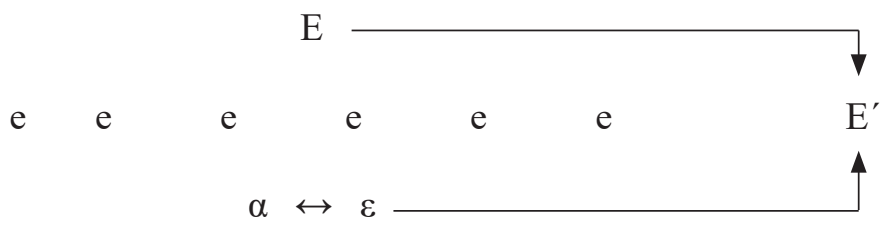

Figure 5. Metonymical context

The metonymical context creates a close or remote analogy with the extra-literary world and its domain is the topic structure of the literary text. There are three sub-categories:

- (a) Analogy: Individual signifieds correspond with particular elements of the extra-literary world and merge into such complexes as exist in the signified real world; the author selects the features of the depicted layer of the real world to achieve representativeness. This is the "synecdoche" context that is typical of realistic literature.

- (b) Model: The meaning complex is not realistically depicted but "modelled" - there is a distinct abstract plan underlying the meaning complex. A model can be metonymical (the model as a whole metonymically depicts a certain feature or layer of reality) or metaphorical (a metaphor is the "key" to the meaning of the whole complex; it is a transition to the metaphorical context).

- (c) Associative context: In this type of context, meanings of different kinds are freely combined.

For both (b) and (c), an addition might be necessary - the complex meaning $\mathrm{E}$ becomes the signifier of a higher order sign:

$\mathrm{e} \rightarrow \mathrm{E} \rightarrow \mathrm{A}^{\prime} \leftrightarrow \mathrm{E}^{\prime}$

Example (1): The metonymical context "house"

e: concrete meanings (setting, visual aspects etc.) 
e: abstract meanings associated with the house (life together with a partner, meetings with friends, protection)

$\mathrm{E}$ : complex meaning (description of the house)

$\mathrm{A}^{\prime}$ : the complex meaning (E) becomes the signifier of the higher order sign

$E^{\prime}:$ the house as a home and a positive value.

Example (2): The metonymical context "composition of the short story"

The short story consists of five paragraphs. For each paragraph, the basic metonymic scheme $(e \rightarrow E)$ applies, i.e. each paragraph is a sign formed by elementary signs with an unmotivated relation between the signifiers and signified, and the above mentioned addition ( $\mathrm{A}^{\prime} \leftrightarrow \mathrm{E}^{\prime}$ ) is necessary (the complex meaning $\mathrm{E}$ becomes the signifier of a higher order sign):

First paragraph:

$\mathrm{e} \rightarrow \mathrm{E}$

E: complex meaning of the first paragraph

$\mathrm{A}^{\prime}$ : the complex meaning (E) becomes the signifier of the higher order sign

$\mathrm{E}^{\prime}$ : first paragraph as an account of what the narrator ("I") remembers.

The same applies for the second, third, fourth and fifth paragraphs:

Second paragraph:

$\mathrm{A}^{\prime}$ : the complex meaning (E) becomes the signifier of the higher order sign

$E^{\prime}$ : second paragraph as an account of what the partner ("you") remembers.

Third paragraph:

$\mathrm{A}^{\prime}$ : the complex meaning $(\mathrm{E})$ becomes the signifier of the higher order sign

$E^{\prime}$ : third paragraph as an account of what the partner considers "drama".

Fourth paragraph:

$\mathrm{A}^{\prime}$ : the complex meaning (E) becomes the signifier of the higher order sign

$E^{\prime}$ : the fourth paragraph as an account of what people remember (the contrast between "snow" and "shroud", which is meant both literally and metaphorically) and of what the narrator remembers (the meaning "snow as a kiss" introducing the metaphor "snow is love"); this is an example of context merging - the metonymical and metaphorical contexts in this case.

Fifth paragraph:

$\mathrm{A}^{\prime}$ : the complex meaning $(\mathrm{E})$ becomes the signifier of the higher order sign

$E^{\prime}$ : the fifth paragraph as an account of what happens with love (based on the "snowplow" metaphor; it is again an example of the metonymical and metaphorical context merging). 
This analysis of the five paragraphs of the text as higher order signs and an overview of their meanings E' reveals the composition of the text:

$\mathrm{E}^{\prime}$ : the first paragraph as an account of what the narrator ("I") remembers (it begins with I remember).

$E^{\prime}$ : the second paragraph as an account of what the partner ("you") remembers (it begins with You remember it differently).

$E^{\prime}$ : the third paragraph as an account of what the partner considers "drama".

$E^{\prime}$ : the fourth paragraph as an account of what people remember (the contrast between "snow" and "shroud") and of what the narrator remembers ("snow as a kiss").

$E^{\prime}$ : the fifth paragraph as an account of what happens with love (based on the "snowplow metaphor").

The contrast between the first and second paragraphs is of special interest. It (a) presents as opposing two views of the same events (and thus creates the context "people perceive and remember differently") and two main characters (who are referred to by the pronouns "I" and "you" and never by their names). It (b) foregrounds the principle of contrast that is vital for the text interpretation because contrasts are present at other places and levels of the text (e.g. "death vs. love", "black vs. white", "field of snow in the past vs. dots of white in the present"). What is also important is the merging of literal and metaphorical meanings.

Example (3): the associative context "visitors' stories"

e: individual stories the visitors told ("ring on the beach", "Popsicles on the pavement")

E: visitors' stories

$\mathrm{A}^{\prime}$ : the complex meaning (E) becomes the signifier of the higher order sign

$E^{\prime}$ : narrator's inclination to interpret casual events as something unusual with deeper meaning.

\subsubsection{Metaphorical context}

The basic element of the metaphorical context is the individual metaphor. The meaning of an elementary sign becomes the signifier of the higher order sign whose meaning is metaphorical as suggested by the schematic representation:

$\mathrm{a} \leftrightarrow \mathrm{e} \rightarrow \mathrm{A} \leftrightarrow \mathrm{E}$ or:

\begin{tabular}{|l|l|}
\hline $\mathrm{a}$ & \\
\hline $\mathrm{e}$ & $\mathrm{A}$ \\
\hline & $\mathrm{E}$ \\
\hline
\end{tabular}

Figure 6. Individual metaphor 
Both the literal meaning (e) and the figurative meaning (E) are part of the individual sign. Discovering the relationship between them, i.e. uncovering the metaphorical meaning, is a complex cognitive process, possibly more demanding than uncovering other types of meaning relationships. Metaphors can thus be seen as an invitation to the active participation of the reader in the interpretation of the text, the more so because the individual metaphor might become a "stratified" or "multiple" metaphor:

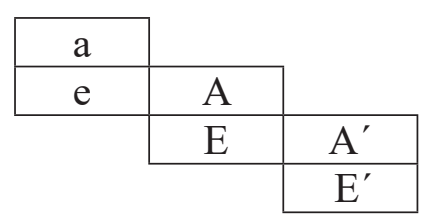

Figure 7. "Multiple" metaphor

An example would be the metaphor "snow is love" that was already introduced in Figure 2:

\begin{tabular}{|l|l|l|}
\hline $\begin{array}{l}\text { a: } \\
\text { the word "snow" }\end{array}$ & \multicolumn{2}{|l}{} \\
\hline $\begin{array}{l}\text { e: } \\
\text { small soft white } \\
\text { pieces of ice that fall } \\
\text { from the sky and } \\
\text { cover the ground }\end{array}$ & $\begin{array}{l}\text { A: } \\
\text { small soft white } \\
\text { pieces of ice that fall } \\
\text { from the sky and } \\
\text { cover the ground }\end{array}$ & \\
\hline & $\begin{array}{l}\text { E: } \\
\text { love }\end{array}$ & $\begin{array}{l}\text { A': } \\
\text { love, friendship, } \\
\text { home }\end{array}$ \\
\cline { 2 - 3 } & $\begin{array}{l}\text { E': } \\
\text { meaningful values }\end{array}$ \\
\hline
\end{tabular}

Figure 8. The multiple metaphorical sign "snow is love"

Once we uncover or accept this interpretation ("snow is love"), we have what might be called "a key" to the text as this metaphorical meaning explains the meaning of other signs:

Example (4): The sign "snowplow"

e: references to snow as a part of the setting

$\mathrm{E}$ : the plot takes place in winter

$\mathrm{A}^{\prime}$ : the complex meaning (E) becomes the signifier of the higher order sign

$E^{\prime}$ : metaphorical meaning (snow as a metaphor of love and removing of snow as a metaphor of "removing" love)

$\mathrm{A}^{\prime} \leftrightarrow \mathrm{E}^{\prime}$ : snowplow as a metaphor 
The metaphorical context is created from the signs (individual metaphors) described above. The literal and the metaphorical meanings merge here, as is the case with individual metaphors.

The chain of interpretation continues - the snowplow is described as something that is always out there and thus it can be perceived as a kind of external force that "removes" love. This motif is repeated in the short story under analysis and in other short stories by the same author. It is expressed by both metaphorical and literal meanings (e.g. an accident, a death of a friend). It is a part of the motif "the world is upside down" which is the leitmotif of Beattie's early literary work: Meaningful values are transient, never last long, they are always destroyed because there is an external force that removes them, but it is not just this external force - it is also, and perhaps more importantly within the context of her short stories, an internal force, something inside us that makes us to destroy meaningful values. This interpretation provides an explanation of other motifs of the short story that might otherwise prove difficult to understand.

Example (5): The context "snow scene outside the house"

Remember the night, out on the lawn, knee-deep in snow, chins pointed at the sky as the wind whirled down all that whiteness? It seemed that the world had been turned upside down, and we were looking into an enormous field of Queen Anne's lace. Later, headlights off, our car was the first to ride through the newly fallen snow. The world outside the car looked solarized.

The meaning of this scene is a complex of meanings drawing from different resources (literal, metaphorical, visual) and merging different contexts existing in the text. If we accept the "snow is love" metaphor, we interpret other meanings accordingly, e.g.:

They are deep in snow $=$ in love.

The world is upside down = love and other meaningful values disappear the way snow does.

Their car was the first to break the whiteness of snow = it was them who destroyed their love.

The "snow is love" metaphor is thus the "key" that "unlocks" the meanings of interrelated meaning complexes; it ensures the coherence of the whole text and creates a link to other texts by the same author.

So far I have focused on the way the model can be used by the translator to explore the meaning potential of the ST to be re-created it in the TT. It could also help the translation critic to evaluate whether and how the meaning complexes of the ST were re-created in the TT. By briefly surveying the remaining contexts, I will seek to introduce the model as a tool that can assist the translator in his/her decision-making processes. 


\subsection{The form activation context}

The basic scheme of the form activation context is:

$\mathrm{a} \rightarrow \mathrm{E}:$

The lower order signifiers create the signified of the meaning complex. The individual signifiers unite to form a context that becomes the signified of a meaning; the set of "material" signals (e.g. styles, rhythmical structures, composition schemes, genre conventions etc.) represent a choice, and as with any choice, it has its meaning equivalent.

Example (6):
a: ellipsis
a: contracted forms
a: italics conveying emphasis
...
E: the mode of discourse (written to be read as if told).

This context is highly relevant to translation. An understanding of the meaning (E) of the forms (a) used in the ST is the basis of functional equivalence: the translator aims at conveying the meaning, using forms that are conventional in the target language, and can thus signal this meaning to the target reader. In Example (5), once the translator is aware of the meaning (E), he/she chooses colloquial grammatical forms and lexical items to convey this meaning in Czech.

Moreover, the form activation context highlights the way in which the author exploits the formal possibilities and options of the source language: For example, by referring to the two main characters by pronouns and not by their names, the author makes use of the morphological vagueness of English - she is not quite clear about the gender of the characters. There is a hint that one of them is female (Somebody grew up, fell in love, and spent a winter with her lover in the country.), a hint that the you person is male (you, in the white towel turban, like a crazy king of the snow) and pragmatic presuppositions (the features characterising the narrator are more likely to be associated with a woman, the features characterising the "you" person are more likely to be associated with a man). Thus the gender of the two main characters is a matter of interpretation. Due to the structural differences between English and Czech (i.e. the rich morphology of the Czech language, the subject - verb agreement in this case), the translation into Czech has to be much more specific. The translator has to use verb endings that in the past tense signal the gender of the person referred to by a pronoun (the English gender neutral verb forms, e.g. I drove, I sat, you brought in, you said, must have gender-specific endings in Czech) and thus make the characters' gender explicit. 


\subsection{The mythical context}

The basic scheme of the mythical context is:

$\mathrm{s} \rightarrow \mathrm{A}:$

Whole elementary signs become the signifier of a meaning complex $(\mathrm{s} \rightarrow \mathrm{A})$ :

\begin{tabular}{|c|c|}
\hline $\mathrm{a}$ & $\mathrm{A}$ \\
$\mathrm{y}$ & \\
\hline & $\mathrm{E}$ \\
\hline
\end{tabular}

Figure 9. Mythical context

Unlike in other contexts, where it was possible to separate the signifier from the signified, in this context appears "an undifferentiated sign, a primary merging of the signifier and the signified, indeed a mythical 'unity' of a word and an 'idea', word and object. [...] Such a materialization of the sign is typical of semiotic systems of primeval cultures, of magic formulas and myths and, as Barthes asserted, it is utilized also by modern societies" (Červenka 1992: 92).

This context is similar to the metaphorical context, the two sharing the possibility of combining elementary signs to create higher meaning complexes.

Example (7): the context "snow as a kiss"

(Even now, saying "snow", my lips move so that they kiss the air.)

a: phonemes, words

e: lips kiss the air when saying "snow"

s: lips kiss the air when saying "snow", i.e. the lips pronounce the sounds / snəo/, specifically the vowel

A: lips kiss the air when saying "snow", i.e. the lips pronounce the sounds /snəo/, specifically the vowel, and their round shape suggests kissing

E: "snow as a kiss" (and a key to understand the metaphor "snow is love"). Here again, translation considerations are interesting, even more so than in Example (6), where it was possible to separate the meaning from the forms conveying it (the mode of discourse). In Example (7), form and content cannot be separated; pronouncing the sounds of the direct Czech equivalent snih /sňi:x/ does not involve rounding the lips and thus it does not prompt the image of lips kissing the air - the vowel /i:/ actually achieves the opposite effect. As a result, the direct equivalent would not suffice as a translation equivalent due to the inseparability of form and meaning, and the translator would need to devise a creative solution to this problem.

\subsection{The metalinguistic and intertextual context}

Whole elementary signs become the signified of a meaning complex $(\mathrm{s} \rightarrow \mathrm{E})$. This context is the domain of metalanguage and intertextuality: 


\begin{tabular}{|c|c|}
\hline $\mathrm{a}$ & $\mathrm{E}$ \\
$\mathrm{yn}$ & \\
\hline & $\mathrm{A}$ \\
\hline
\end{tabular}

Figure 10. Metalinguistic and intertextual context

Example ( $8 \mathrm{a}, \mathrm{b})$ : Intertextual signals of authorial style (the formula "something is as hopeless/pointless as..." is present in other short stories by the same author and expresses disillusionment and the motif "the world is chaos"):

(8 a):

a: It was as hopeless as ...

e: the literal (not intertextual) meaning of the words

E: the words (both their form and content) as a signal of intertextuality and authorial style

A: It was as hopeless as giving a child a matched cup and saucer (the actual formulation of the sentence).

$(8 \mathrm{~b})$ :

a: It's as pointless as ...

e: the literal (not intertextual) meaning of the words

E: the words (both its form and content) as a signal of intertextuality and authorial style

A: It's as pointless as throwing birdseed on the ground while snow still falls fast (the actual formulation of the sentence).

\subsection{The montage context}

The basic scheme of the montage context is:

$\mathrm{s} \rightarrow \mathrm{S}$ :

The lower order signs create a meaning complex:

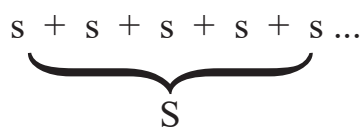

Figure 11. Montage context

This context presupposes a large degree of independence of individual signs. It can be exemplified by a collection of poems or short stories, a novel divided into independent layers distinguished by dissimilar content and formal means, and mosaic-like combinations of relatively stabilized signs (folk songs, fairy tales). Even here, the complex meaning is not a mere sum of the meanings of individual signs as there is always a meaning complex $(\varepsilon)$ attached. Its signifiers are the ways in which signs are combined, relations between the signs, specific features of the whole set etc. 


\subsection{The visual context}

The visual context is not a part of Červenka's account of semiotic analysis. I believe however that this inclusion of the nonverbal visual aspect into the model of semiotic analysis will prove rewarding as it might uncover additional meaning sources. What I call the visual context is, at this point, a proposal for further research and a topic for a follow-up study rather than a developed analysis. I believe that under this label, three aspects are to be investigated:

- visualisation as a method of analysis, recommended by Levý (1998: 56-57) and developed e.g. by Kuzmičová (2012) ${ }^{2}$, as demonstrated by example (9);

- nonverbal meaning resources such as gestures, facial expressions or body language described verbally in the text (see e.g. Poyatos, 1977);

- visual effects that might be created in the body of the text, as demonstrated by example (10).

Whilst not denying their meaning-making potential, I do not mean to cover graphic elements such as fonts or layout, illustrations and framing devices such as the book jacket or title page under this label.

Example (9): Visualisation/reader's presence as an analytical tool

Remember the night, out on the lawn, knee-deep in snow, chins pointed at the sky as the wind whirled down all that whiteness? It seemed that the world had been turned upside down, and we were looking into an enormous field of Queen Anne's lace.

The scene contains the previously discussed meanings of "remembering" and the metaphorical meaning "snow is love". The meaning "the world is upside down" is conveyed verbally and as an image whose meaning can be best captured by visualisation/reader's presence: we usually visualize "the world" as having dark ground and light sky - here we need to imagine the whole scene to realize why it is "upside down": the lawn is covered with snow, therefore it is light, it is night, therefore the sky is dark. Visualising the dark sky with falling snow helps us to understand the meaning of "enormous field of Queen Anne's lace". The visual image can assist the translator looking for a TL expression: the referent of the poetic expression Queen Anne's lace is a quite unpoetic wild carrot. In Czech, the dictionary equivalent of wild carrot would not suffice, as it is distinctively unpoetic and does not evoke the image of a great amount of little white flowers against the background of the dark sky. The translator would be searching for a word capable of evoking this image, e.g. nevěstin závoj [bridal veil] = baby's breath/Gypsophila.

Example (10): Visual effects - colour symbolism and its use in the text composition The visual effects are created by the way in which certain key words are distributed throughout the text. The keywords belong to two contrasting groups; the first group suggests "whiteness" and includes the words snow, winter, white, white- 
ness, love, kiss; the second group suggests "darkness" and includes the words night, black, dark, died, shroud. The first group words prevail in paragraphs 1, 4 and 5 and imply positive associations; the second group words prevail in paragraphs 2 and 3 and imply negative associations. In all paragraphs, one group prevails, but the other is also present. This design might visually communicate the yin and yang design, which corresponds with the calm, detached and unemotional yet empathetic tone of the short story.

\section{Conclusions}

The study has further elaborated a previously designed model of translationrelated semiotic text analysis and empirically tested its usefulness. The model proved an effective tool for conceptualising meaning-creating within the ST and meaning-re-creating within the TT as it:

- goes "against" the linearity of the text and helps to perceive the way in which meaning contexts are created throughout the text (at different places and at different levels of the text), and from language units of different kinds and sizes (sounds, words, sentences, paragraphs, composition, narrative voice, perspectivisation etc.);

- smoothly and continuously merges textual with contextual and verbal with non-verbal meaning resources;

- uses style as a principle unifying the whole text, conceiving of meaning as a fusion of both form and content - a fusion that is interpreted by the translator and which is actively re-created in the TT; at the same time, it puts style into perspective by subordinating it to the semiotic mode of text processing.

Consequently, it can be argued that the model is suitable for (literary) translation purposes and is worth developing further (specifically Section 3.6 as the visual context was only sketched out) and testing on a larger corpus of STs and TTs. Such research would bring more empirical data on the transfer of meaning in translation, on the choices made by the translators and on their creativity.

\section{Notes}

$1 \quad \mathrm{E}=$ expression, $\mathrm{R}=$ relation, $\mathrm{C}=$ content.

$(\mathrm{ERC}) \mathrm{RC}=$ the sign of lower order becomes the level of expression for the sign of the higher order. At both the elementary and the complex levels, further combinations of both aspects of the sign (signifier/signified) are assumed (Červenka 1992: 79, 147-148).

2 Kuzmičová presents "an embodied theory of presence" (i.e., the reader's sense of having entered a tangible environment" and argues that "presence arises from a first-person, enactive process of sensorimotor simulation/resonance, rather than from mere visualizing from the perspective of a passive, third-person observer" (2012: 23). 


\section{References}

Beattie, Ann (1986) Snow. In: Where You'll Find Me. New York: Simon and Schuster.

Boase-Beier, Jean (2006) Stylistic Approaches to Translation. Manchester: St Jerome.

Catford, J. C. (1965) A Linguistic Theory of Translation: An Essay in Applied Linguistics. London: Oxford University Press.

Cosculluela, Cécile (2003) Semiotics and translation studies: An emerging interdisciplinarity. Semiotica 145(1/4): 105-137.

Červenka, Miroslav (1992) Významová výstavba literárního díla. Praha: UK.

Dosse, Francois (1997) Histoire du structuralisme, 11. Le chant du cygne, de 1967 anos jour; trans. D. Glassman as History of Structuralism. Volume 2: The Sign Sets, 1967-Present. Minneapolis: University of Minnesota Press.

Fořt, Bohumil (2006) Estetická funkce, norma, hodnota jako spletité fakty. Česká literatura 23: 131-139.

Gorlée, Dinda L. (1994) Semiotics and the problem of translation: With special reference to the semiotics of Charles $S$. Peirce. Amsterdam: Rodopi.

Hatim, Basil and Ian Mason (1990) Discourse and the Translator. London and New York: Longman.

Kuzmičová, Anežka (2012) Presence in the reading of literary narrative: A case for motor enactment. Semiotica 189(1/4): 23-48.

Levý, Jiří (1998) Umění překladu. Praha: Ivo Železný.

Nida, Eugene A. and Charles R. Taber (1969) The Theory and Practice of Translation. Leiden: E. J. Brill.

Nuyts, Jan (2007) Cognitive linguistics and the history of linguistics. In: Gearaerts, Dirk and Hubert Cuyckens (eds.) The Oxford Handbook of Cognitive Linguistics. Oxford: Oxford University Press, 589-607.

Popovič, Anton (1975) Teória umeleckého prekladu: Aspekty textu a literárnej metakomunikácie. Bratislava: Tatran.

Poyatos, Fernando (1977) Forms and functions of nonverbal communication in the novel: A new perspective of the author-character-reader relationship. Semiotica 21(3/4): 295-337.

Snell-Hornby, Mary (1988) Translation Studies: An Integrated Approach. Amsterdam: John Benjamins.

Torop, Peeter (2000) Towards the semiotics of translation. Semiotica 128(3/4): 597-609.

Zehnalová, Jitka (in print) The Czech structuralist tradition and a model of translation-related semiotic analysis. Translatologica Pragensia. 


\section{Appendix}

The analysed text

\begin{tabular}{|c|c|c|c|}
\hline Author & \multicolumn{3}{|l|}{ Ann Beattie } \\
\hline Title & \multicolumn{3}{|l|}{ Snow } \\
\hline Publication media & \multicolumn{3}{|l|}{ printed book } \\
\hline Format & $\begin{array}{l}\text { short story } \\
\text { collection }\end{array}$ & \multicolumn{2}{|c|}{$\begin{array}{l}\text { Where You'll Find Me. Simon \& Schuster: New } \\
\text { York, } 1986 .\end{array}$} \\
\hline Text type (genre) & \multicolumn{3}{|l|}{ short story } \\
\hline Literary movement & \multicolumn{3}{|l|}{ American minimalism } \\
\hline \multirow{2}{*}{$\begin{array}{l}\text { Typical features of } \\
\text { authorial style }\end{array}$} & \multirow{2}{*}{$\begin{array}{l}\text { favourite themes } \\
\text { and their expressive } \\
\text { means }\end{array}$} & world is chaos & the world is upside down \\
\hline & & disillusionment & $\begin{array}{l}\text { something is as hopeless } \\
\text { pointless as... }\end{array}$ \\
\hline Overall tone & \multicolumn{3}{|l|}{ subdued, unemotional } \\
\hline Mode of discourse & \multicolumn{3}{|c|}{ written to be read as if told } \\
\hline \multirow{3}{*}{$\begin{array}{l}\text { Symbols used for } \\
\text { analysis }\end{array}$} & blue highlights & \multicolumn{2}{|l|}{ "whiteness" } \\
\hline & grey highlights & \multicolumn{2}{|l|}{ "darkness" " } \\
\hline & underlinings & \multicolumn{2}{|c|}{ favourite themes and their expressive means } \\
\hline
\end{tabular}

\section{SNOW}

I remember the cold night you brought in a pile of logs and a chipmunk jumped off as you lowered your arms. "What do you think you're doing in here?" you said, as it ran through the living room. It went through the library and stopped at the front door as though it knew the house well. This would be difficult for anyone to believe, except perhaps as the subject of a poem. Our first week in the house was spent scraping, finding some of the house's secrets, like wallpaper underneath wallpaper. In the kitchen, a pattern of white-gold trellises supported purple grapes as big and round as Ping-Pong balls. When we painted the walls yellow, I thought of the bits of grape that remained underneath and imagined the vine popping through, the way some plants can tenaciously push through anything. The day of the big snow, when you had to shovel the walk and couldn't find your cap and asked me how to wind a towel so that it would stay on your head - you, in the white towel turban, like a crazy king of the snow. People liked the idea of our being together, leaving the city for the country. So many people visited, and the fire place made all of them want to tell amazing stories: the child who happened to be standing on the right corner when the door of the ice-cream truck came open and hundreds of Popsicles cascaded out; the man standing on the beach, sand sparkling in the sun, one bit glinting more than the rest, stooping to find a diamond ring. Did they talk about amazing things because they thought we'd turn into one of them? Now I think they probably guessed it wouldn't work. It was as hopeless as giving a child a matched cup and saucer. Remember the 
night, out on the lawn, knee-deep in snow, chins pointed at the sky as the wind whirled down all that whiteness? It seemed that the world had been turned upside down, and we were looking into an enormous field of Queen Anne's lace. Later, headlights off, our car was the first to ride through the newly fallen snow. The world outside the car looked solarized.

You remember it differently. You remember that the cold settled in stages, that a small curve of light was shaved from the moon night after night, until you were no longer surprised the sky was black, that the chipmunk ran to hide in the dark, not simply to a door that led to its escape. Our visitors told the same stories people always tell. One night, giving me a lesson in storytelling, you said, "Any life will seem dramatic if you omit mention of most of it."

This, then, for drama: I drove back to that house not long ago. It was April, and Allen has died. In spite of all the visitors, Allen, next door, had been the good friend in bad times. I sat with his wife in their living room, looking out the glass doors to the back yard, and there was Allen's pool, still covered with black plastic that had been stretched across it for winter. It had rained, and as the rain fell, the cover collected more and more water until it finally spilled onto the concrete. When I left that day, I drove past what had been our house. Three or four crocus were blooming in the front - just a few dots of white, no field of snow. I felt embarrassed for them. They couldn't compete.

This is a story, told the way you say stories should be told: Somebody grew up, fell in love, and spent a winter with her lover in the country. This, of course, is the barest outline, and futile to discuss. It's as pointless as throwing birdseed on the ground while snow still falls fast. Who expects small things to survive when even the largest get lost? People forget years and remember moments. Seconds and symbols are left to sum things up: the black shroud over the pool. Love, in its shortest form, becomes a word. What I remember about all that time is one winter. The snow. Even now, saying "snow", my lips move so that they kiss the air.

No mention has been made of the snowplow that seemed always to be there, scraping snow off our narrow road - an artery cleared, though neither of us could have said where the heart was.

JitKa Zehnaloví obtained her MA and PhD degrees in English and German philology from Palacký University in Olomouc, Czech Republic. She is Assistant Professor at the Department of English and American Studies of this University. She has published in the fields of Translation Studies and Translation Quality Assessment and is a co-editor of the peer-reviewed conference proceedings Olomouc Modern Language Series.

Address: Mgr. Jitka Zehnalová, Dr., Palacký University, Philosophical Faculty, Department of English and American Studies, Křŕžkovského 10, 77180 Olomouc, Czech Republic. [email: jitka. zehnalova@upol.cz] 